\title{
ARTICLE
}

\author{
A. Hernández $\cdot$ M. Jébrak $\cdot$ P. Higueras $\cdot$ R. Oyarzun \\ D. Morata · J. Munhá
}

\section{The Almadén mercury mining district, Spain}

Received: 23 October 1998 / Accepted: 4 January 1999

\begin{abstract}
The Almadén district is the largest mercury concentration in the world, with a total content of about $250000 \mathrm{t}$ of mercury, nearly one third of the known total mercury resources of the Earth. Mercury has been exploited since the Celtic and Roman times, with peak production during the Renaissance and between 19391945. The district is hosted by a Paleozoic synclinorium overlying Precambrian rocks. The Paleozoic sequence comprises epicontinental quartz arenite rocks, including black shales and quartzites. Diatremes, alkaline lavas of different composition, and late tholeiitic diabases account for the Ordovician to Devonian magmatism. The tectonic setting of this complex suite corresponds to the
\end{abstract}

Editorial handling: DR

\section{A. Hernández}

Minas de Almadén y Arrayanes S.A., Almadén (Ciudad Real), Spain

M. Jébrak

Université du Québec à Montréal,

Département des Sciences de la Terre,

CP 8888, suc. Centre Ville,

Montréal (QUE) H3C 3P8, Canada

P. Higueras $(\square)$

Departamento de Ingeniería Geológica y Minera,

Escuela Universitaria Politécnica de Almadén,

Universidad de Castilla La Mancha, Plaza M. Meca 1,

13400 Almadén, Spain

E-mail: phiguera@igem-al.uclm.es

R. Oyarzun

Departamento de Cristalografía y Mineralogía,

Facultad de Ciencias Geológicas,

Universidad Complutense, 28040 Madrid, Spain

D. Morata

Departamento de Geología,

Facultad de Ciencias Físicas y Matemáticas,

Universidad de Chile, Casilla 13518,

Correo 21, Santiago, Chile

J. Munhá

Departamento de Geôciencias,

Universidad de Lisboa, Campo Grande,

Ed. C5, $5^{\circ} .1700$ Lisboa, Portugal intraplate type. The mercury deposits of Almadén can be classified into two main types: type 1, early stratiform type ores characterized by cinnabar deposition on the lower Silurian quartzites (Criadero quartzite; e.g. the Almadén and El Entredicho deposits), and type 2, late discordant orebodies (e.g. Las Cuevas), largely hosted or related to diatremes (the 'frailesca rocks') of alkaline basaltic composition. In type 1 cinnabar was deposited during diagenesis, in relation to hydrothermal circulation driven by magmatic activity. Type 2 include a variety of deposits having in common the discordant character of the orebodies (e.g. veins, stockworks, massive replacements), and their wide dispersion along the stratigraphic column, i.e. from Lower Silurian (e.g. Nueva Concepción) to Upper Devonian (e.g. Corchuelo).

\section{Introduction}

The Almadén district of Spain constitutes one of the major and most unusual concentrations of metals on Earth. Before mining it is estimated that the area contained about $250000 \mathrm{t}$ of mercury, and about a third of the known global mercury resources. Mercury grades reach 8 to $10 \%$ historically, but more recently are about 3 and $5 \%$.

Although the Almadén district has been classically known for its stratiform mineralizations (e.g. the Almadén and El Entredicho deposits), hosted by the Criadero quartzite (Llandovery), other structural types are present, some of them of economic importance. An example of the latter is provided by Las Cuevas, a fully discordant deposit stratigraphically located at the top of the Silurian sequence.

This work summarizes the mining history, the geological setting and the description of selected mercury deposits from the Almadén district. It concentrates on recent data regarding geology and alteration processes, and discusses some current problems. 


\section{History of the district}

The mining history of the Almadén district began some 2000 years ago. Almadén was known as Sisapo until the tenth century, which means mine in the Celtic language. Romans used cinnabar as a vermilion red pigment, mainly for social occasions. Arabs gave the name Al-maaden (the ore) to the deposit, and developed medical and alchemist applications. Production in the fourteenth and fifteenth centuries was also used in the treatment of leather. In 1555, Bartolomé de Medina discovered the use of mercury in silver processing in Pachuca (Mexico). Thus, from the middle of the sixteenth century Almadén had a major strategic importance for the colonization of America, and became one of the largest early mining and metallurgical centres in Europe. Total production during the sixteenth and seventeenth centuries is estimated as $17250 \mathrm{t}$ of mercury, which is very significant taking into account the mining difficulties and numerous accidents (fires, floods). During the eighteenth century, production began to decrease because of the competition from the Idria deposit (former Yugoslavia). In 1700, a high-grade zone was discovered (Mina del Castillo). Mining techniques were modernized by German engineers from Freiberg, who were supported by the creation of the Almadén School of Mines in 1777, the fourth in the world. The first steam engines were installed in 1805 , which ended the manual removal of water. In the nineteenth century there was first an increase in production, followed by fluctuations due to management problems. Peak production was achieved in 1941, with 82000 flasks of mercury $(>2830 \mathrm{t})$.

In the past, mercury was one of the leading export products of Spain, with price peaking at US\$ 571/flask in 1965. Concerns about its environmental impact arose from the Minamata incident in Japan, and a similar problem in Iraq, that were responsible for a sharp decrease in the world price to US\$ 121/flask in 1976 (Fig. 1). A strong recovery in the late 1970s was due to the development of alkaline batteries. Present-day uses also include chlorocaustic processes, amalgams, paints, and several industrial and drug applications. In 1990, however, the price collapsed again, which

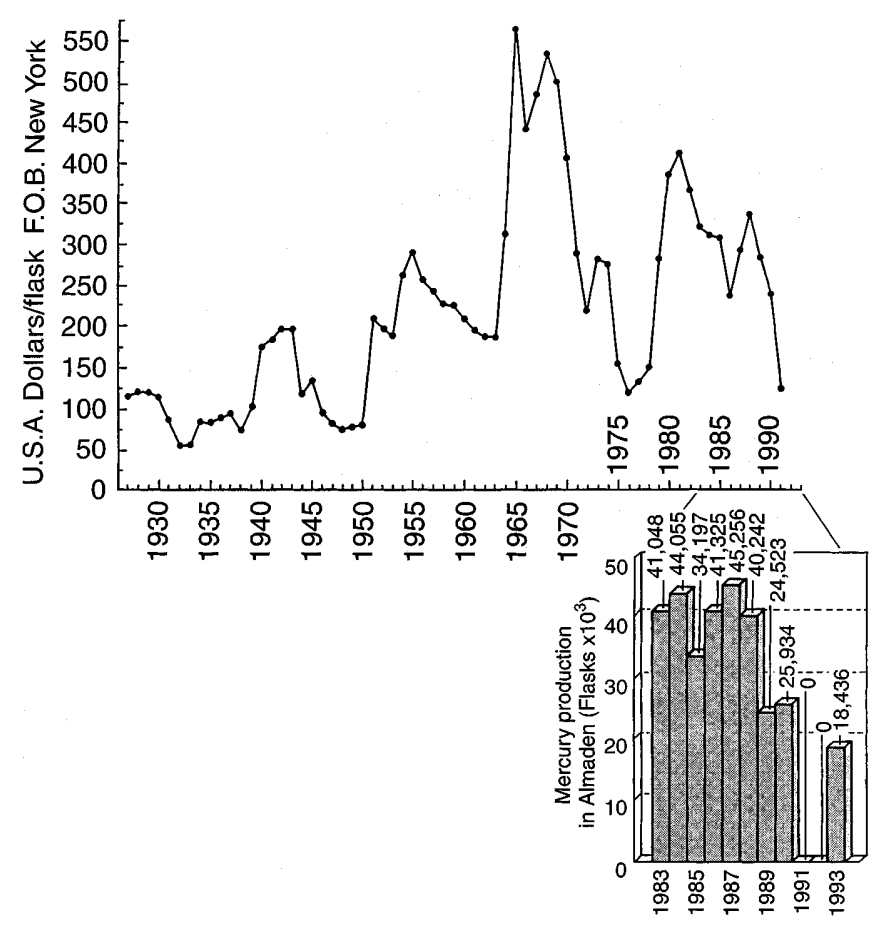

Fig. 1 Evolution of the price of mercury since 1927 and evolution of the mercury production in Almadén since 1983 triggered a crisis in Almadén in 1991. The following year recorded no production, and only a very small output (20 000 flasks) was reached in 1993-1994. At present, production is in the order of $25000-35000$ flasks per year.

The scientific history of the district began with the studies of Prado (1855). Early works by Ransome (1921) and Van der Veen (1924) interpreted the deposit as epigenetic and related it to the Los Pedroches Hercynian granite intrusion, located $30 \mathrm{~km}$ to the south. The volcaniclastic nature of the 'frailesca' rocks (friarlike rock, after its textural similarity to the patchy aspect of the robes of the early Franciscan monks) was recognised in the late 1950s (Almela and Febrel 1960). The stratigraphy began to be understood in the 1960s (Almela et al. 1962; Tamain 1972). Petrographic and sedimentologic studies were carried out by Saupé (1973, 1990) and were influenced by the syngenetic school of thought present in Europe at that time (Laboratorie de Géologie Appliquée 1973). More recent works investigated the isotope geochemistry (Arnold and Saupé 1985; Rytuba et al. 1989; Saupé and Arnold 1992) and compared the deposit with active geothermal systems. The relationship between ore and volcanic rocks was highlighted by Hernández (1984) and led to the discovery of El Entredicho orebody.

\section{Geologic overview}

The Almadén area is located in the central part of the Iberian peninsula, $300 \mathrm{~km}$ south of Madrid (Fig. 2). The district lies in the Central-Iberian zone of the Hesperian (Iberian) Massif (Julivert et al. 1972). Three cycles of deposition can be distinguished in this zone: late Precambrian, Paleozoic and late Cenozoic. All the mercury ore has been found in the Paleozoic rocks. Precambrian formations comprise very thick units $(>8000 \mathrm{~m})$ of greywacke and shale of Riphean age, and variable shelf facies (up to $1000 \mathrm{~m}$ thick) of Vendian age. A large Paleozoic synclinorium overlies the Precambrian basement rocks.

The Paleozoic series starts with Lower Ordovician sedimentary rocks, transgressing over the Precambrian series along a basal unconformity. The Lower Ordovician rocks include shales, sandstone and quartzite with some conglomerate lenses at the base. The white Armorican Quartzite of Arenigian age is a regional marker, and it is overlain by fossil-rich (trilobites, graptolites) dark grey to black shales of Llanvirn-Llandeilo age (Calymene Shale). A second light coloured quartzite unit of Caradoc age (Canteras Quartzite) represents the culmination of a regressive stage starting at the top of Calymene Shale. By the end of Ordovician times, sedimentation became more shale-rich and sedimentary conditions were constant within the series. A very thin unit of limestone beds with abundant corals and brachiopods is indicative of a warming of the climate. Alkaline diatremes (frailesca rocks) are intercalated in the Ordovician sequence.

The Silurian-Devonian series comprises a $2200 \mathrm{~m}$ thick sequence of quartz-arenites, rhythmically interlayered sandstones and shales, black shales, alkaline basaltic rocks, and diatremes (Fig. 3). The sedimentary rocks were deposited under marine conditions, including several regressive megasequences (Saupé 1973; García Sansegundo et al. 1987). Detailed descriptions of the stratigraphic units are given by Tamain (1972), Saupé (1973) and García Sansegundo et al. (1987).

The Llandoverian Criadero quartzite is the main host to mercury mineralization (stratiform deposits). It comprises two quartzite members separated by an intermediate shale unit. The lower member is lensoid and is well developed in the old mine of Almadén. It consists of the two white quartzite lenses of San Pedro and San Diego. The upper member has a wide lateral extent, and is composed of two black quartzite lenses (San Nicolás and San Francisco). These quartzites are generally medium-grained and are well cemented. They display abundant sedimentary structures (ripple marks, cross-bedding) and may have been deposited at the intersection of a delta with a tidal flat grading towards a shelf. Their total thickness varies regionally from 50 to $70 \mathrm{~m}$ on the southern flank of the synclinorium to less than $10 \mathrm{~m}$ in the northern 
Fig. 2 Location of the Almadén district in the Iberian Peninsula and location of the major mercury producers of the Almadén district

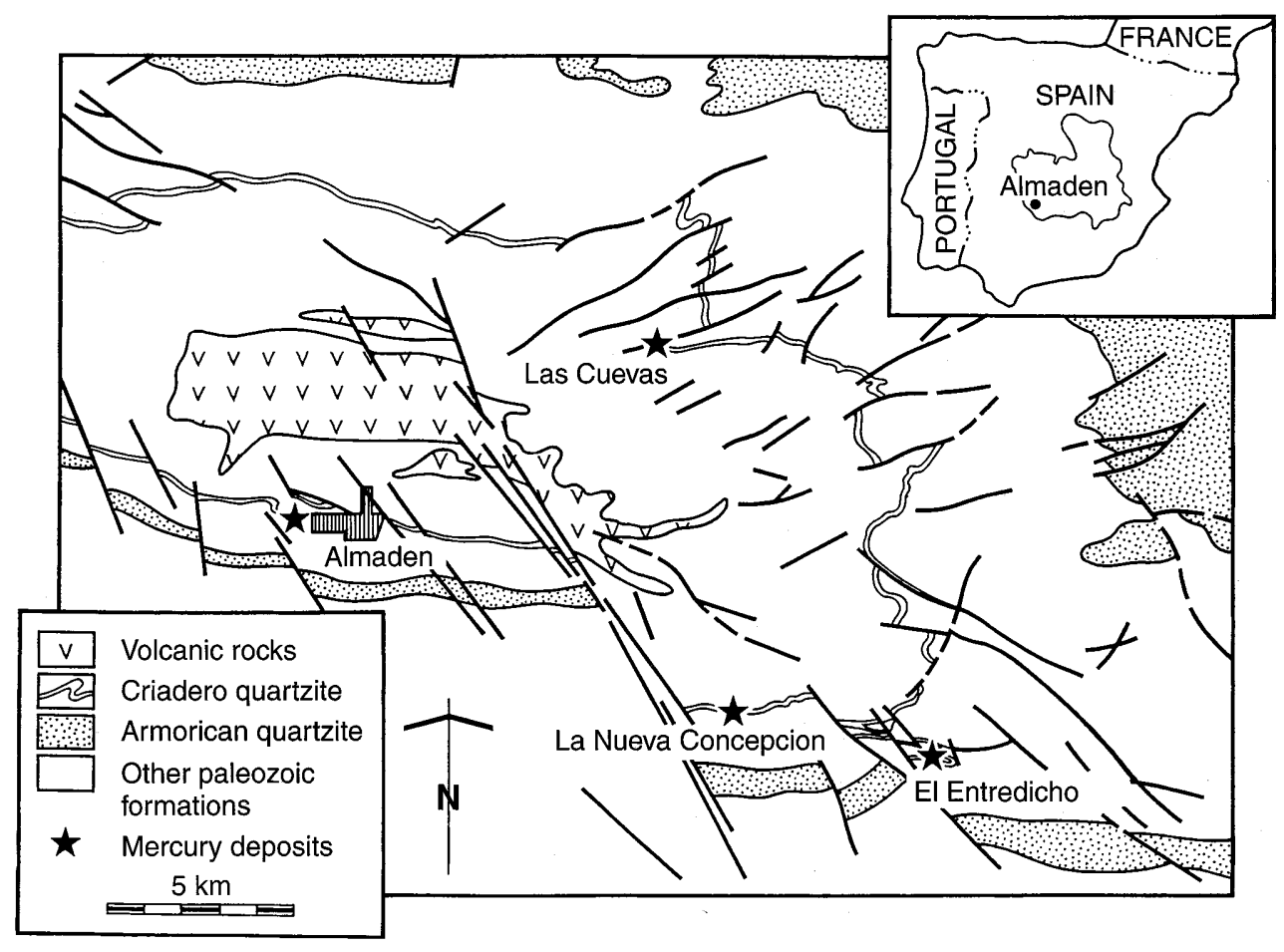

flank. This reflects a significant paleogeographic gradient, partly enhanced by asymmetric deformation processes.

The Almadén sequence is characterized by a remarkably persistent magmatic activity spaning from Ordovician to Devonian. The magmatic rocks include alkaline porphyric lavas ranging in composition from basanite and nephelinite to rhyolite (Higueras and Munhá 1993) and diatremes composed of brecciated rocks, the frailesca rocks. These diatremes cross-cut the stratigraphic units at a slight angle in most of the mercury mines, and have an inverted conical shape, with a diameter up to several hundred metres. They are composed of pyroclastites and epiclastites, which are bedded in places. They have been interpreted by Saupé (1990) as representing magmatism contemporaneous with the sedimentation, and therefore correspond to shallow, submarine, phreatomagmatic eruptions. The open conical shape indicates an emplacement in non-fully consolidated rocks, as at the Argyle lamproite pipe, Western Australia (Bower and Jaques 1990). Other types include subvolcanic mafic rocks (diabase) of tholeiitic affinity (Higueras and Munhá 1993), representing a late episode of magmatic activity. We will enlarge on this matter in the following section.

Three episodes of deformation have been recognized in the Almadén synclinorium (Hernández 1984; Saupé 1990). The first phase formed a narrow elongated synclinorium, up to $100 \mathrm{~km}$ long, trending $\mathrm{N} 110^{\circ}$, overturned to the north, with incipient flow schistosity. This major phase of folding has been dated at $335 \pm 15 \mathrm{Ma}(\mathrm{Rb} / \mathrm{Sr}$; Nägler et al. 1992). This age is compatible with the existence of a discordant Stephanian B-C coal basin postdating the main Hercynian deformation. The second phase is characterized by $\mathrm{N} 30^{\circ}$ trending folds within sinistral brittle-ductile shear zones striking $\mathrm{N} 110^{\circ}$, and some dextral $\mathrm{N} 80^{\circ}$ striking faults. Kilometre-scale offsets are observed in the northern part of the Almadén synclinorium (Soldevila 1983; Jébrak and Hernández 1995). Most of the faults display a polyphase brittle evolution, with an early strike-slip and reverse movements associated with compression varying from E-W to NE-SW, and a late episode of NS-directed brittle extension. The stratigraphic pile has been hydrothermally altered to the pumpellyite, early anchizone, facies (Higueras et al. 1995). Pleistocene deposits form a very thin $(30-50 \mathrm{~m})$ but very conspicuous cover and correspond to alluvial fan conglomerates.

\section{Magmatism}

The magmatic activity in the Almadén district deserves special attention due to the many relationships between the volcanic rocks and the different mercury mineralisations. The magmatic rocks described in the Almadén syncline (Higueras, 1995) include the following petrographic types:

1. Pyroclastic rocks, that occur as diatreme bodies (frailesca rock), composed of completely alterated olivine-basalt clasts, and sedimentary clasts. Outcrops of these rocks are typical of diatremes; the bodies have an inverted conical shape and cross-cut the hosting rocks.

2. Porphyric rocks, ranging in composition from basanites/nephelinites to rhyolites, through olivinebasalts, pyroxenitic-basalts (pyroxene cumulates), trachybasalts and trachytes. Basanites/nephelinites and olivine basalts are the main petrographic types, while the intermediate and felsic members are less abundant. Minerals in these rocks include olivine phenocrystals; diopsidic pyroxene as phenocrystals and matrix; analcite as phenocrystals and matrix; plagioclase; biotite phenocrystals in intermediate rocks; and $\mathrm{K}$-feldspar and quartz as phenocrystals and matrix of the felsic rocks. Late magmatic kaersutitic amphibole and Ti-rich biotite are also conspicuous in the mafic types. Textures are porphyric, with crystalline matrix, and often vesicular.

3. Subvolcanic mafic rocks with doleritic texture, which allows classification of these rocks as diabases. Major 

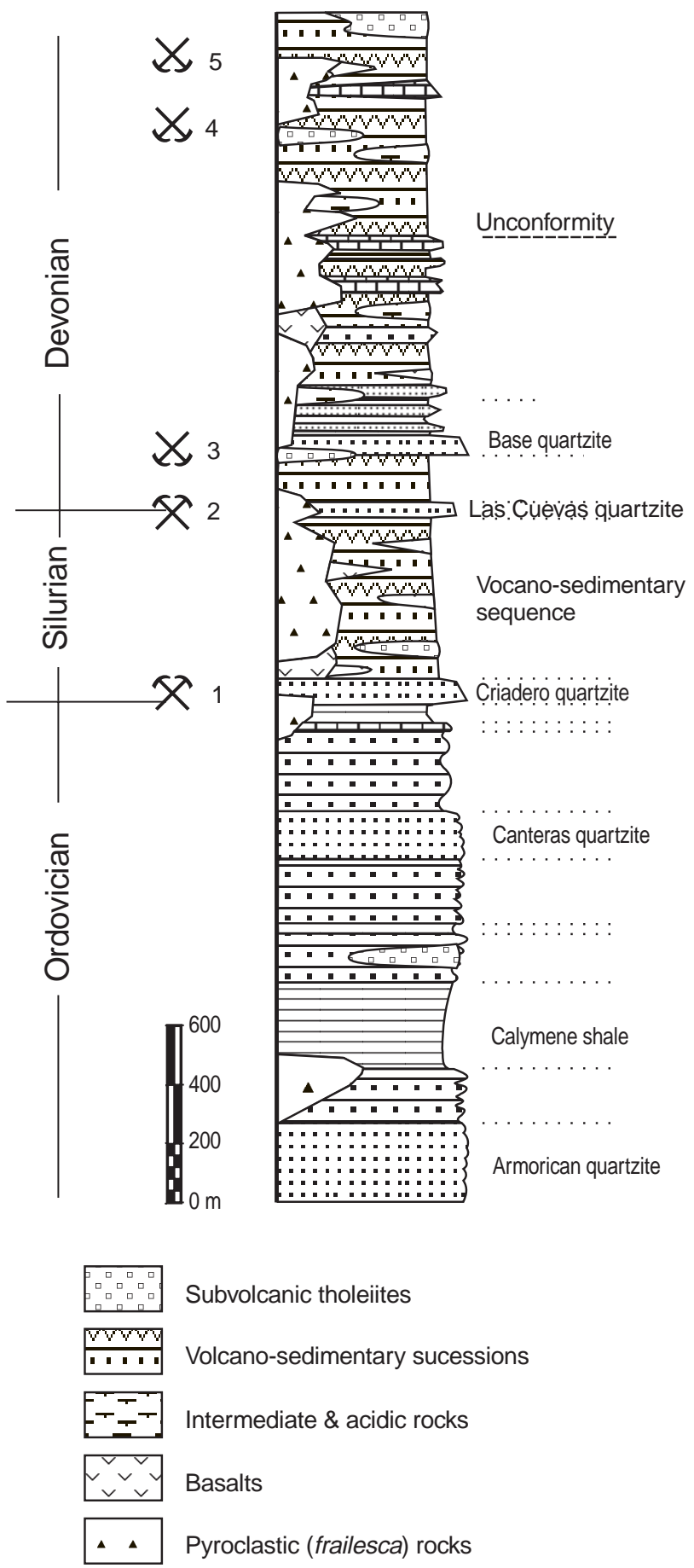

Fig. 3 Stratigraphic column of the Paleozoic units in the Almadén synclinorium, with location of $\mathrm{Hg}$ deposits. 1, Position of type 1 deposits (Almadén, El Entredicho and Vieja Concepción), and La Nueva Concepción (type 2). 2, Position of Las Cuevas (type 2). 3, Position of El Burcio (type 2). 4, Position of Guadalperal (type 2). 5 , Position of Corchuelo (type 2). Modified from Higueras (1995)

minerals are augitic pyroxene and calcic plagioclase. Minor minerals are olivine as small phenocrystals in olivine diabases, and K-feldspar and quartz (interstitial or in graphic intergrowths) in quartz-diabases. Olivine diabases crop out as sills of metric scale thickness, while the quartz-diabases occur as small stocks, and sills of up to $5 \mathrm{~m}$ thick.

4. Ultramafic rocks, present as clasts in the pyroclastic rocks, and as xenoliths in the least differentiated basalts. They are highly altered, although it is still possible the identification of olivine $(50-80 \%)$, pyroxene, and minor unaltered spinel, which allows classification of these rocks as spinel lerzholites.

The distribution of the different volcanic rock types in the stratigraphic column shows some remarkable features. In the Ordovician sequence, only the frailesca pyroclastic rocks are present. In the Criadero quartzite the frailesca diatremes are common and basanite/nephelinite levels, often with ultramafic xenoliths (El Entredicho and Vieja Concepción mines). In the Silurian and Lower Devonian sequences, frailesca and basaltic levels are widely present. In the Upper Devonian, intermediate rocks (trachytes) are quite common, together with pyroclastic and basaltic levels. In the highest part of the syncline Paleozoic sequence (Upper Frasnian), all the spectra of volcanic rocks (pyroclasts and rhyolites to olivine basalts) are found and predominant in the stratigraphic record.

High $\mathrm{Ni}$ and $\mathrm{Cr}$ contents for basanites, olivine basalts, olivine diabases and pyroxene basalts, as well as their high $[m g]$ values $(=\mathrm{MgO} / \mathrm{MgO}+\mathrm{FeO})$ indicate a mantle origin for these magmas, and suggest that they were derived from primitive liquids.

The primitive mantle normalized spiderdiagrams (Fig. 4) shows the major differences between these rocks. Alkaline porphyric rocks (basanites/nephelinites, olivine basalts and trachybasalts) show similar patterns. Also, these porphyric rocks have strong similarities to the olivine diabase pattern. Major differences between the alkaline and the transitional to tholeiitic rocks are related to the presence of a positive $\mathrm{Nb}$ anomaly, higher $\mathrm{TiO}_{2}$ and HFSE contents, and higher LREE/HREE ratios in the former ones. It is also remarkable for the absence of a negative $\mathrm{Nb}$ anomaly in the quartz-diabases. The application of the Meschede (1986) $2 \mathrm{Nb}: \mathrm{Zr} / 4$ : Y diagram (Fig. 5) shows that all the porphyritic rocks plot in the field of within-plate alkaline basalts, while the quartz-diabases plot in the field of within-plate tholeiites.

The petrographic evolution from basanite dominant mafic terms in the Silurian to trachybasaltic, trachytic and even rhyolitic rocks in the Upper Devonian is a conspicuous indicator of the geochemical evolution of the Almadén magmas. The LREE/HREE ratios display a clear decreasing evolution from the Silurian samples, through Devonian, to intrusive quartz-diabases. According to White and McKenzie (1995) this pattern is indicative of a decrease in the generation depth, which could be from about $100 \mathrm{~km}$ for Silurian rocks, to $60 \mathrm{~km}$ for the tholeiitic quartz-diabases. These estimated depths are in agreement with the presence of spinel lerzholites as xenoliths in the Silurian basaltic lavas.

According to Higueras (1995) the Almadén magmas were generated from a volatile-, and incompatible ele- 


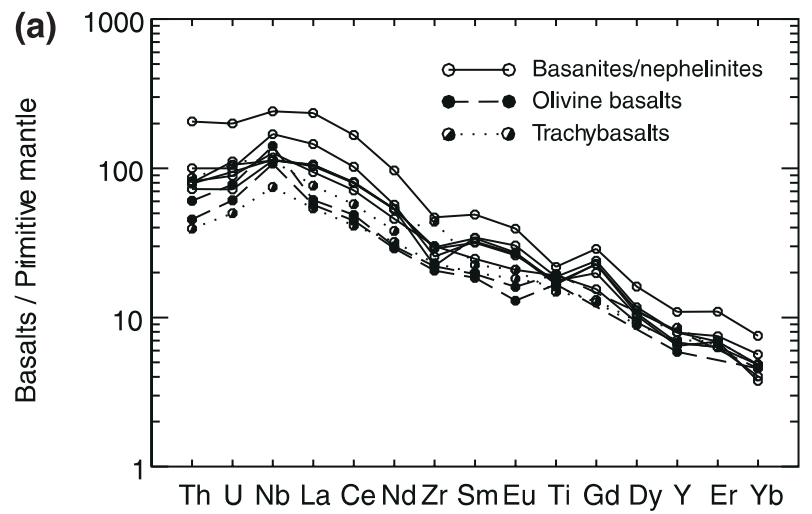

Fig. 4a,b Primitive mantle normalized spiderdiagrams for: a porphyric rocks, and $\mathbf{b}$ subvolcanic rocks. Normalization values after Taylor and MacLennan (1985)

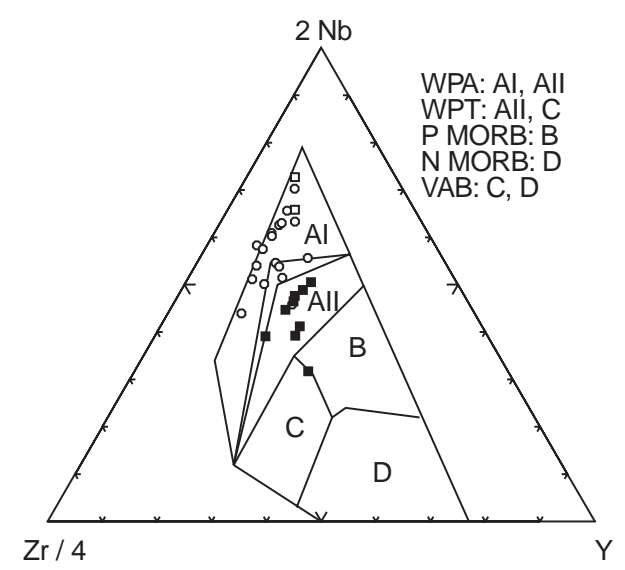

Fig. $5 \mathrm{Nb}-\mathrm{Zr}-\mathrm{Y}$ diagram (after Meschede 1986) for mafic magmatic rocks of the Almadén district. Open circles: basalts; black squares: dolerites. WPA: within-plate alkaline basalts; WPT: within-plate tholeiites; $P$ MORB, $N$ MORB: mid-ocean ridge basalts; VAB: volcanic arc basalts

ment-rich asthenospheric source of EM-I type, by partial melting processes, with rates increasing from 1.6-6\% during the Silurian, to $4-9 \%$ in the Devonian, and finally from $10-17.5 \%$ for the subvolcanic transitional to tholeiitic rocks.

\section{Ore deposit types and alteration processes}

Two types of mercury deposits can be recognized in the Almadén district (Hernández 1984): stratiform (type 1) and discordant (type 2) (Fig. 6). Type 1 deposits are the largest and include those of Almadén (Fig. 7) and El Entredicho. These mineralizations are hosted by the Criadero quartzite, i.e. they are stratigraphically restricted to a single stratigraphic horizon at the base of the Silurian. Type 2 deposits are fully discordant and hosted or related to diatremes, although the mineralization can be also hosted by other lithologies, including

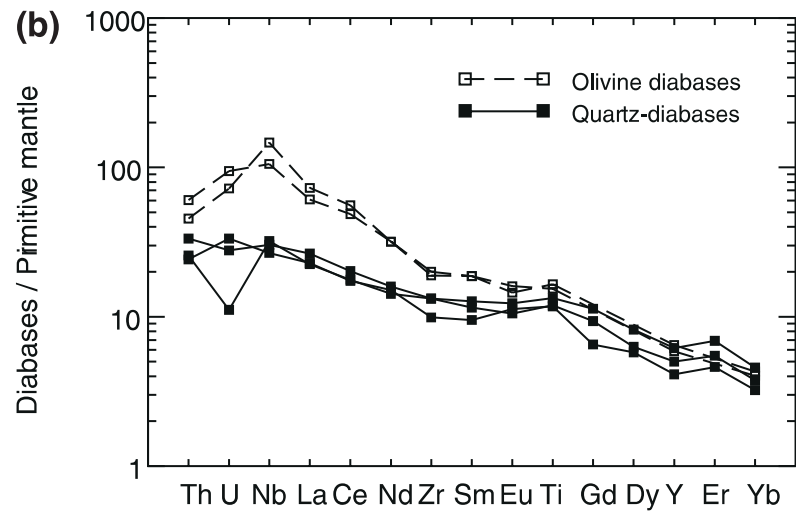

sedimentary and volcanic (lava type) rocks. An example is provided by the Las Cuevas deposit, hosted by an extremely folded and sheared rock sequence of Late Silurian age comprising frailesca rocks, lavas, shales and quartzites. The two main orebodies are $25-30 \mathrm{~m}$ wide, have an irregular shape, extend vertically for about 100 $150 \mathrm{~m}$ and are hosted by frailesca rocks and metasedimentary units (metapelites and quartzites) (Higueras et al. 1999). Type 2 deposits have in common their wide dispersion along the stratigraphic column. They can be found in the Lower Silurian (Nueva Concepción), Upper Silurian (Las Cuevas), Lower Devonian (El Burcio) or Upper Devonian (Guadalperal and Corchuelo). Hydrothermal alteration in type 1 deposits is characterized by the extensive development of $\mathrm{Ca}-\mathrm{Mg}-\mathrm{Fe}$ carbonates, chlorite and quartz, as well as Cr-rich mica (fuchsite) in ultramafic xenoliths (Morata et al. 1997).

At a much larger scale, the whole sequence of Silurian to Devonian magmatic rocks are pervasively altered. This regional alteration (e.g. Higueras et al. 1999) consists of the following mineral assemblages: (1) quartz-chlorite-albite-carbonates ( \pm ankerite, \pm siderite, \pm magnesite, \pm calcite) (mainly found in the alkaline basaltic rocks), and (2) chlorite \pm prehnite \pm pumpellyite \pm epidote \pm actinolite (restricted to the isolated bodies of tholeiitic diabases). This alteration is locally overprinted by a muscovite/illite-kaolinite-pyrophyllite assemblage, which is typically associated with the late, type 2 ore deposits (e.g. Las Cuevas). The pattern is clearly depicted by the $\mathrm{CO}_{2}$ distribution map of the district (Fig. 8), which shows a deep low at Las Cuevas, roughly outlining the destruction of the pervasive carbonatization related to the regional alteration.

\section{Metallogeny}

The location of the major mercury deposits of the Almadén synclinorium is controlled by two main factors: (1) the mineralization is controlled by the same Silurian horizon (Criadero quartzite) and therefore appears to be stratabound (type 1), and (2) the mineralization occurs mainly near, or less commonly within, alkaline volcanic rocks and diatremes that were respectively deposited and intruded during sedimentation of the marine facies 
Fig. 6 Comparison between the different styles of mineralization in the Almadén district: Vieja Concepción, El Entredicho, Nueva Concepción, Las Cuevas and Almadén deposits
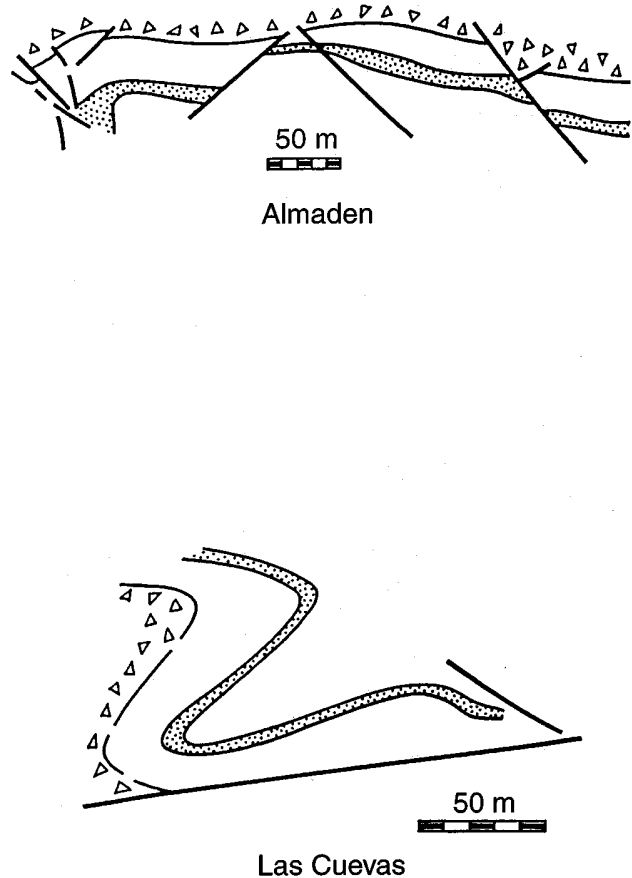

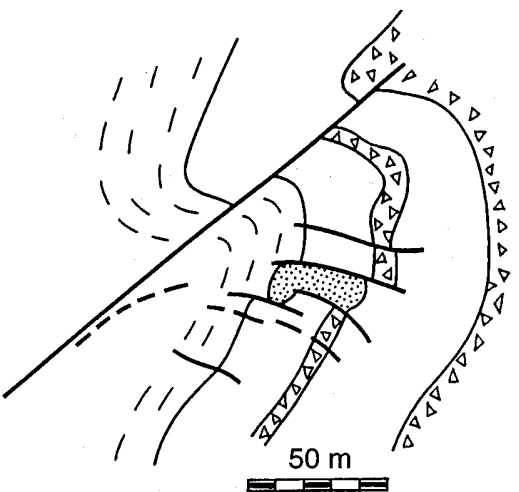

La Nueva Concepcion

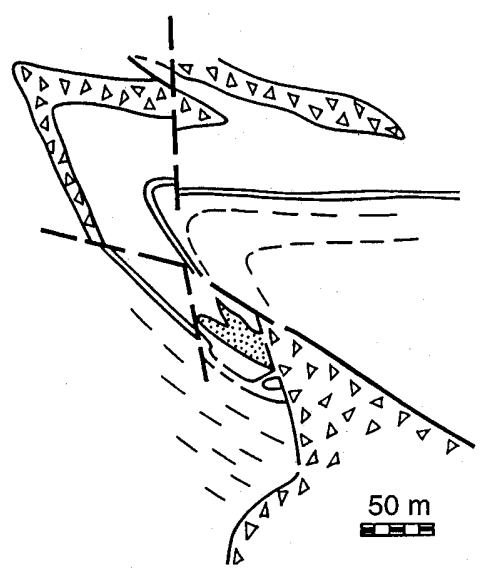

El Entredicho (types 1 and 2). Whether type 2 deposits, all of them spatially associated with diatremes, represent Hercynian remobilizations from a single mineralized stratigraphic horizon (Criadero quartzite) remains controversial. Alternatively, they could represent mineralizations formed in response to hydrothermal activity driven by the magmatism, during different, discrete episodes along the geologic history of Almadén. Folding and shearing during the Hercynian orogeny do not help to elucidate this important and vital issue.

There are still relatively few fluid inclusion determinations for the district. Some preliminary data on quartz and dolomite in veins from the Almadén deposit (type 1) shows that late fluids had a low-salinity aqueous composition (5 equivalent wt. $\% \mathrm{NaCl}$ ). Temperatures of homogenization vary between $240{ }^{\circ} \mathrm{C}$ (quartz) and $85{ }^{\circ} \mathrm{C}$ (late dolomite). Low temperatures of first melting imply the presence of $\mathrm{Ca}^{++}$or $\mathrm{Mg}^{++}$(García Iglesias and Loredo Pérez 1989). The absence of metacinnabar indicates a temperature below $315-345{ }^{\circ} \mathrm{C}$ (Potter and Barnes 1978). Preliminary fluid inclusion data for the Las Cuevas deposit (type 2) (Higueras et al. 1999) indicate low to moderate salinities (1-13 equivalent wt.\% $\mathrm{NaCl})$ and homogenization temperatures between 150 $375{ }^{\circ} \mathrm{C}$ (mode $=220{ }^{\circ} \mathrm{C}$ ). The crystals of quartz on which the study was carried out are anhedral, up to $100 \mu \mathrm{m}$ in diameter, and contain abundant inclusions of cinnabar, thus suggeting that they may be coeval with the mercury depositional process.

Calvo and Guillemany (1974), Arnold and Saupé (1985), Rytuba et al. (1989) and Saupé and Arnold (1992) carried out sulphide isotope studies. In the Almadén mine, $\delta^{34} \mathrm{~S}$ varies between -0.1 and $9.03 \%$ for cinnabar, and -4.34 to $20 \%$ for pyrite. The larger variations in pyrite are probably due to its multiple origin, with some pyrites being early diagenetic, and other clearly epigenetic. $\delta^{34} \mathrm{~S}$ values of cinnabar seems to increase near the margins of the frailesca crater in Almadén and El Entredicho (Rytuba et al. 1989). The Las Cuevas $\delta^{34} \mathrm{~S}$ isotopic ratio of cinnabar is anomalously heavier, around 13-14\%o. Although Rytuba et al. (1989) suggested a relationship with an early caldera, these heavy values could be related to a remobilization process and a late input of heavy sulphur from the black shale. Moreover, Saupé (1990) discusses the possibility of kinetic isotopic disequilibrium in the district.

Eichmann et al. (1977) and Arnold and Saupé (1985) analyzed $\delta^{13} \mathrm{C}$ and $\delta^{18} \mathrm{O}$ in carbonate and $\delta^{13} \mathrm{O}$ in quartz. $\delta^{13} \mathrm{C}$ measurements on calcites suggest that hydrothermal $\mathrm{CO}_{2}$ was derived largely from a deep-seated source. 
W

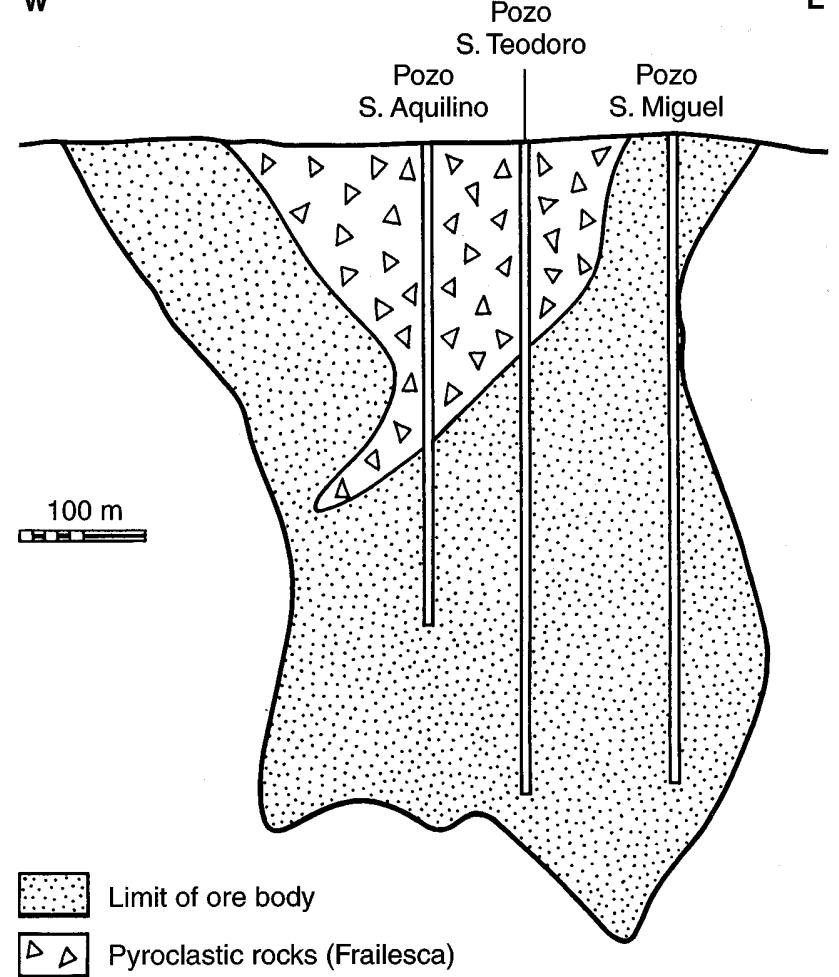

Fig. 7 Idealized longitudinal section of the ore zone in the Almadén mine (after Saupé 1990)

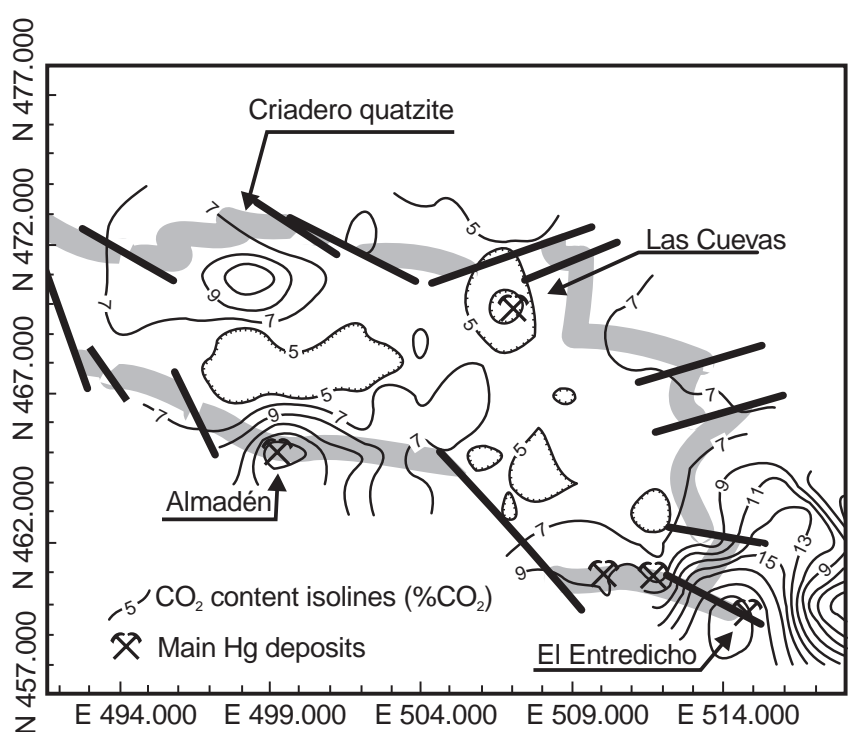

Fig. $8 \mathrm{CO}_{2}$ distribution map at the regional scale in the Almadén district (after Higueras 1995)

However, due to poor understanding of the alteration sequence, the significance of these data remains uncertain.

The origin of the type 1 mercury ores has long been a source of discussion: what is the cause of the concentration in large amounts of such a rare metal? There is still no definitive consensus about the origin of the Al- madén district. The type 1 deposits belongs to the large class of volcano-sedimentary mineralizations where the relative importance of early exhalative and late structural concentration has been widely discussed. Saupé (1973) argued for an almost pure synsedimentary model of deposition, with a source of mercury in the black shales or in the volcanism. Hernández (1984), Saupé (1990), Borrero and Higueras (1990) and Ortega and Hernández (1992) highlighted the control by alkaline diatremes and suggested a mantle origin.

Last but not least is the persistence of explosive magmatism (frailesca rocks) along most of the SilurianDevonian sequence. Did this magmatism trigger hydrothermal activity and mercury mineralization at different times during the geologic evolution of Almadén? The magmatic rocks found along the stratigraphic column are pervasively altered to low-grade mineral assemblages (Higueras 1995), i.e. regional alteration. These alteration facies most probably developed within a geologic environment undergoing geothermal-type alteration processes, at the district scale, and under submarine conditions. High-geothermal gradients were provided by coeval magmatic activity, the whole process probably lasting from Early Silurian to Late Devonian. A comparison of the Almadén regional alteration facies to those of modern geothermal analogous (e.g. Icelandic geothermal fields; Liou et al. 1987; Yardley 1989) suggest steep geothermal gradients and mineral formation within the range $\sim 200-300{ }^{\circ} \mathrm{C}$. Although we are certain that hydrothermal activity was long-lived in the Almadén sequence, we cannot say the same regarding $\mathrm{Hg}$ deposition. We know that regardless of the age, type 2 deposits are consistently related to frailesca rocks, however, whether this relationship is 'genetic' or merely 'coincidental' is difficult to tell. Another problem relates to the Ordovician frailesca rocks. If the alkaline diatremes are the ultimate cause of mineralization, why then are no mercury deposits found either within or near to the Ordovician diatremes?

Finally, the present data are clearly not sufficient to understand why the Almadén district contains so much mercury. Some of the key elements missing for a better metallogenic understanding of this giant mineralization are discussed.

\section{Deposition}

There is abundant evidence for an early phase of mercury deposition in the Almadén district. Saupé (1973) emphasized the location of cinnabar crystals between detrital quartz grains and secondary overgrowths in the Criadero Quartzite. However, the reticulate ore is probably associated with hydraulic brecciation, which requires significant fluid overpressure, and consequently an impermeable cap on the top of the quartzite. The rheological contrast between quartzite and shale is able to focus fluids within the quartzitic horizons (e.g. Ridley 1993). Thus, mercury deposition does not seem to be 
Table 1 Main mercury deposits of the Almadén district

\begin{tabular}{|c|c|c|c|c|}
\hline Deposit & $\begin{array}{l}\text { Location } \\
\text { with respect } \\
\text { to the syncline }\end{array}$ & Host-rock & Tonnage & Geometry \\
\hline Almadén & South & Criadero Quartzite & $8000 \mathrm{Mf}$ & Stratabound \\
\hline El Entredicho & South east & Criadero Quartzite & $350 \mathrm{Mf}$ & Stratabound \\
\hline Vieja Concepción & South east & Criadero Quartzite & ? & Stratabound? \\
\hline Las Cuevas & North & $\begin{array}{l}\text { Volcanic rocks and } \\
\text { Quartzite (?) }\end{array}$ & $150 \mathrm{Mf}$ & $\begin{array}{l}\text { Massive replacements } \\
\text { in frailesca rock }+ \\
\text { stockwork in the } \\
\text { hinge of a drag fold } \\
+ \text { stratabound } \\
\text { hydraulic breccias } \\
\text { in Quartzite }\end{array}$ \\
\hline Nueva Concepción & Southeast & $\begin{array}{l}\text { Volcanic rocks and } \\
\text { Criadero Quartzite }\end{array}$ & $185 \mathrm{Mf}$ & Stratabound + faults \\
\hline Nuevo Entredicho & Southeast & Volcanic rocks & $150 \mathrm{kf}$ & Replacement + faults \\
\hline
\end{tabular}

Table 2 Average chemical composition of basic rock types in the Almadén district

\begin{tabular}{|c|c|c|c|c|c|c|}
\hline $\begin{array}{l}\text { Rock type } \\
\text { No. of analysis }\end{array}$ & $\begin{array}{c}\text { Basanites } \\
8\end{array}$ & $\begin{array}{l}\text { Oliv. bas. } \\
6\end{array}$ & $\begin{array}{c}\text { Pirox. bas. } \\
4\end{array}$ & $\begin{array}{c}\text { Trachybas. } \\
3\end{array}$ & $\begin{array}{c}\text { Oliv. diab. } \\
8\end{array}$ & $\begin{array}{l}\text { Qdiab. } \\
5\end{array}$ \\
\hline $\mathrm{SiO}_{2}$ & 38.01 & 44.44 & 39.18 & 49.32 & 43.57 & 50.65 \\
\hline $\mathrm{Al}_{2} \mathrm{O}_{3}$ & 9.84 & 14.22 & 12.12 & 14.69 & 13.70 & 14.29 \\
\hline $\mathrm{Fe}_{2} \mathrm{O}_{3}$ & 1.78 & 1.39 & 1.85 & 1.47 & 1.66 & 1.50 \\
\hline $\mathrm{FeO}$ & 10.67 & 9.96 & 11.11 & 7.80 & 10.13 & 8.00 \\
\hline $\mathrm{MnO}$ & 0.19 & 0.16 & 0.25 & 0.14 & 0.17 & 0.19 \\
\hline $\mathrm{MgO}$ & 12.70 & 9.07 & 11.86 & 5.21 & 9.38 & 5.99 \\
\hline $\mathrm{CaO}$ & 11.11 & 6.83 & 10.16 & 6.84 & 7.52 & 8.22 \\
\hline $\mathrm{K}_{2} \mathrm{O}$ & 0.79 & 0.80 & 0.61 & 1.02 & 0.67 & 0.54 \\
\hline $\mathrm{Na}_{2} \mathrm{O}$ & 1.31 & 1.64 & 1.60 & 3.69 & 1.88 & 3.16 \\
\hline $\mathrm{TiO}_{2}$ & 2.86 & 2.58 & 2.98 & 2.29 & 2.35 & 1.80 \\
\hline $\mathrm{P}_{2} \mathrm{O}_{5}$ & 0.65 & 0.37 & 0.71 & 0.43 & 0.44 & 0.20 \\
\hline LOI & 9.02 & 7.81 & 6.90 & 5.43 & 7.39 & 3.78 \\
\hline SUM & 100.10 & 100.16 & 100.56 & 98.95 & 99.87 & 99.06 \\
\hline $\mathrm{CO}_{2}$ & 6.01 & 3.24 & 3.48 & 3.24 & 3.39 & 0.93 \\
\hline $\mathrm{H}_{2} \mathrm{O}+$ & 3.04 & 4.09 & 3.29 & 2.18 & 3.92 & 2.93 \\
\hline $\mathrm{Cr}$ & 340.00 & 443.67 & n.a. & 146.00 & 414.25 & 185.50 \\
\hline $\mathrm{Ni}$ & 263.63 & 196.17 & 257.50 & 91.33 & 147.63 & 61.60 \\
\hline $\mathrm{Co}$ & 63.00 & 51.00 & 53.50 & 33.00 & 44.57 & 39.50 \\
\hline $\mathrm{Sc}$ & 18.42 & 25.40 & 20.50 & n.a. & 23.65 & 20.80 \\
\hline V & 217.00 & 193.00 & 239.50 & 136.00 & 213.57 & 158.00 \\
\hline $\mathrm{Cu}$ & 58.58 & 46.43 & 62.00 & 27.00 & 58.49 & 57.60 \\
\hline $\mathrm{Pb}$ & 6.38 & 11.17 & 7.00 & 4.67 & 5.25 & 4.40 \\
\hline $\mathrm{Zn}$ & 107.67 & 89.53 & 93.50 & 158.00 & 88.60 & 80.50 \\
\hline $\mathrm{Rb}$ & 33.33 & 2.50 & 24.00 & n.a. & 23.00 & 14.00 \\
\hline $\mathrm{Ba}$ & 1478.50 & 437.00 & 715.00 & 198.00 & 1144.43 & 305.00 \\
\hline $\mathrm{Sr}$ & 939.83 & 469.50 & 738.00 & n.a. & 612.33 & 409.00 \\
\hline $\mathrm{Nb}$ & 68.25 & 47.17 & 66.00 & 51.33 & 54.50 & 17.40 \\
\hline $\mathrm{Zr}$ & 235.13 & 198.00 & 287.50 & 312.33 & 197.50 & 97.60 \\
\hline Y & 23.63 & 23.67 & 27.00 & 27.67 & 19.63 & 17.00 \\
\hline Th & 5.46 & 3.00 & 4.50 & 4.15 & 3.45 & 1.65 \\
\hline $\mathrm{U}$ & 1.68 & 1.10 & 1.40 & 1.40 & 1.33 & 0.40 \\
\hline $\mathrm{La}$ & 61.08 & 31.40 & 51.45 & 35.85 & 35.25 & 12.50 \\
\hline $\mathrm{Lu}$ & 0.24 & 0.23 & 0.27 & 0.28 & 0.23 & 0.19 \\
\hline [mg] & 0.68 & 0.62 & 0.66 & 0.54 & 0.62 & 0.57 \\
\hline$(\mathrm{La} / \mathrm{Lu}) \mathrm{n}$ & 26.39 & 14.17 & 20.36 & 13.70 & 15.96 & 7.01 \\
\hline $\mathrm{Nb} / \mathrm{Y}$ & 2.89 & 1.99 & 2.44 & 1.86 & 2.78 & 1.02 \\
\hline $\mathrm{La} / \mathrm{Nb}$ & 0.89 & 0.67 & 0.78 & 0.70 & 0.65 & 0.72 \\
\hline
\end{tabular}

Major elements in percent by weight. Trace elements in parts per million by weight. LOI: loss on ignition. $[\mathrm{mg}]=\mathrm{MgO} /(\mathrm{MgO}+\mathrm{FeO})$. Rock type abbreviations: Oliv. bas.: Olivine basalts; Pirox. bas.: Piroxenitic basalts; Trachybas: Trachybasalts; Oliv. diabas.: Olivine diabases; Qdiabas: Quartzdiabases directly associated with sea-floor precipitation, but could have resulted from early diagenetic or epigenetic circulation. In addition, some cinnabar concentrations display clearly epigenetic features, especially in orebodies hosted by volcanic rocks. The extent of mercury halos around the ore bodies could provide new con- 
straints on the dispersion of fluid and mode of transportation (nature of the permeability), and at the same time, provide new targets for high $\mathrm{Hg}$ concentrations.

Numerous alteration processes have been documented within and around the mercury deposits of the Almadén district. Several questions arise about their precise timing and geochemical significance. A strong metasomatism with sericitisation appears in post-mineralization dykes at Almadén (Saupé 1973), and argillic alteration is associated with cinnabar deposition in Las Cuevas.

Dating of alteration processes for type 1 deposits $\left({ }^{40} \mathrm{Ar} /{ }^{39} \mathrm{Ar}\right.$; Hall et al. 1997) indicate a wide dispersal of ages, i.e. from $426.9 \pm 2.8$ to $364.3 \pm 3.0 \mathrm{Ma}$. According to Hall et al. (1997) this dispersion could be the result of partial to nearly total argon loss during the Hercynian orogeny. Alternatively, data dispersion could be reflecting the long-lasting, hydrothermal activity during the Silurian-Devonian time-span.

\section{Transport}

The existing geochemical information on the Almadén type 1 deposits suggests that deposition of mercury took place at rather low temperatures, below $240{ }^{\circ} \mathrm{C}$. But there are presently very few data on the composition of the fluids responsible for the transport and deposition of mercury in Almadén.

Recent studies on the Las Cuevas deposit (type 2) (Higueras et al. 1999) indicate the following. The high quartz contents in the proximal alteration, together with the presence of the assemblage pyrophyllite-kaolinite suggests that the local alteration evolved above the quartz saturation line in the $\mathrm{Al}_{2} \mathrm{O}_{3}-\mathrm{SiO}_{2}-\mathrm{H}_{2} \mathrm{O}$ system (Hemley et al. 1980), which constrains the temperature range for the process to $<300{ }^{\circ} \mathrm{C}$. Additionally, the lowest temperature boundary for the system is constrained by the depositional conditions of the assemblage cinnabar + pyrite, which can only form at above $200{ }^{\circ} \mathrm{C}$, in relatively oxidizing, low-pH, S-rich environments (Varekamps and Buseck 1984).

\section{Source}

A major problem with the source of $\mathrm{Hg}$ at Almadén is not only the absolute concentration of $\mathrm{Hg}$ in the district, but the processes by which $\mathrm{Hg}$ became separated from the associated metals. Saupé (1973) proposed mercury preconcentration in the Silurian black shales. The strong affinity of mercury for organic matter is well known, and is the cause of many environmental concerns. His main argument was the high $\mathrm{Hg}$ background (average $4 \mathrm{ppm}$ $\mathrm{Hg}$ ) observed in the Silurian black shale for samples outside the mine, compared to a Clarke value for black shale of $0.37 \mathrm{ppm}$. Alternatively, such background values could also be derived from the same source as the ore bodies, and Saupé $(1973,1990)$ recognizes that the volcanic rocks could also be a potential source of mercury.

Several mercury deposits around the world have shown some unexplained connections with mantle metasomatism (Fedorchuk 1974). The Almadén synclinorium and its eastern extension is the only place where ultramafic rocks (xenoliths) have been observed. This, together with geological and geochemical data for the Almadén volcanic rocks, suggest rifting processes and mantle plume activity during the early Paleozoic (Higueras and Munhá 1993). The composition of the Crspinel (picotite) in the ultramafic xenoliths of the El Entredicho mine is similar to that of spinel in the ultramafic rocks related to the Californian mercury deposits (Ortega and Hernández 1992). Russian authors have also noted the possible connection of mercury with several types of ultramafic rocks (Fedorchuk 1974). However, the mercury content of the mantle and the likehood of magmatic concentration remain poorly known. The geochemical behaviour of $\mathrm{Hg}$ is rather similar to those of $\mathrm{Sb}$ and $\mathrm{Ag}$, and could be introduced into the surface by the degassing of an intrusion (Verekamp and Buseck 1984; Rytuba and Heropoulos 1992). Alternatively, a spatial association might not be directly significant for an origin of the mercury, but could indicate favourable geochemical conditions for the transport of $\mathrm{Hg}$, such as the abundance of $\mathrm{CO}_{2}$ and/or $\mathrm{CH}_{4}$, produced either during the volcanic process or during retrograde alteration (Morency et al. 1986).

The $\mathrm{Hg}$-content of an enriched garnet-lherzolite mantle source enriched in incompatible elements and its evolution during magmatic differentiation should therefore be investigated, together with studies of the mineralogical location of $\mathrm{Hg}$ in mafic minerals. Further developments in understanding transport and deposition processes would also benefit from investigations of the $\mathrm{Hg}$ sources.

Acknowledgements We would like to thank Minas de Almadén y Arrayanes S.A., which authorised this publication. The research was partly conducted during the sabbatical stay of MJ in the Key Centre for Teaching and Research in Strategic Mineral Deposits, The University of Western Australia, directed by D. Groves, who is specially thanked. Financial support for PH from the University of Castilla-La Mancha, "Financiación Interna" program, is also acknowledged.

\section{References}

Almela A, Febrel T (1960) La roca frailesca de Almadén: un episodio tobáceo en una formación basáltica del Siluriano superior. Not Com Inst Geol Min Esp 59: 41-72

Almela A, Alvarado M, Coma E, Felgueroso C, Quintero I (1962) Estudio geológico de la región de Almadén. Bol Inst Geol Min Esp 73: 193-327

Arnold M, Saupé, F (1985) Sulphur isotope data from the Almadén mercury mining district (C. Real, Spain). Abstr Fortsch Mineral Dtsch $63 \mathrm{p} 11$

Borrero J Higueras P (1990) Nuevos conocimientos sobre la geología y génesis de los yacimientos de mercurio de Almadén (Ciudad Real). Bol Geol Min 101-6: 48-65 
Bower GL, Jaques AL (1990) Argyle (AK1) diamond deposit. In: Hughes, EE. (eds) Geology of the mineral deposits of Australia and Papua New Guinea. Australasian Institute of Mining Metallurgy, Monogr 14, Melbourne, vol 1: 697-706

Calvo FA, Guillemany JM (1974) Mineralogénesis del mineral de mercurio de Almadén. In: Congr Int Mercurio, Barcelona. vol 1: $189-200$

Crespo JL (1987) Investigación mediante sondeos del área de "La Nueva Concepción". Intern Rep, Minas de Almadén

Eichmann R, Saupé F, Schidlowsky M (1977) Carbon and oxygen isotope studies of rocks in the vicinity of the Almadén mercury deposits (Province of C. Real, Spain). In: Klemm D, Schneider HJ (eds) Time- and stratabound ore deposits, Springer-Verlag, Berlin Heidelberg New York, pp 396-405

Fedorchuk VP (1974) Genetic and commercial types of mercury deposits. In: Congr Int Mercurio, Barcelona. vol 1: 117-143

García Iglesias J, Loredo Pérez J (1989) Sobre las condiciones de removilización y precipitación de mercurio en el yacimiento de Almadén. III Congr Geoquímica de España I: 131-138

García Sansegundo J, Lorenzo Alvarez S, Ortega E (1987) Mapa Geológico Nacional a escala 1:50 000, sheet 808 (Almadén). Institute Geologia y Minero España, Madrid

Hall CM, Higueras P, Kesler SE, Lunar R, Dong H, Halliday AN (1996) Dating of alteration episodes related to mercury mineralization in the Almadén district, Spain. Earth Planet Sci Lett 148: 287-298

Hemley JJ, Montoya JW, Marinenko JW, Luce RW (1980) Equilibria in the system $\mathrm{Al}_{2} \mathrm{O}_{3}-\mathrm{SiO}_{2}-\mathrm{H}_{2} \mathrm{O}$ and some general implications for alteration/mineralization processes. Econ Geol 75: 210-228

Hernández AM (1984) Estructura y génesis de los yacimientos de mercurio de la zona de Almadén. PhD diss., University of Salamanca, Spain, $120 \mathrm{p}$

Higueras P, Munhá J (1993) Geochemical constraints on the petrogenesis of mafic magmas in the Almadén mercury mining district. Terra Abstract 5: 12-13

Higueras P (1995) Procesos petrogenéticos y de alteración de las rocas magmáticas asociadas a las mineralizaciones de mercurio del distrito de Almadén. PhD Thesis, University of Granada. Servicio de Publicaciones, Univ. de Castilla-La Mancha, $270 \mathrm{p}$

Higueras P, Morata D, Munhá J (1995) Metamorfismo de bajogrado en facies prehnita-pumpellyita en las metabasitas del sinclinal de Almadén. Bol Soc Esp Mineral 18: 111-125

Higueras P, Oyarzun R, Lunar R, Sierra J, Parras J (1999) The Las Cuevas deposit, Almadén district (Spain): unusual case of deepseated advanced argillic alteration related to mercury mineralization. MD 34: 211-214

Jébrak M, Hernández A (1995) Tectonic deposition of mercury in the Almadén district (Las Cuevas deposit, Ciudad Real, Spain). Mineralium Deposita 30: 413-432

Julivert M, Fontboté JM, Ribeiro A, Conde LEN (1972) Mapa tectónico de la Península Ibérica y Baleares a escala 1:1 000 000. Instituto Geológico y Minero España, Madrid

Laboratoire de Géologie Appliquée, Université de Paris, France (1973) Some major concepts of Metallogeny (Consanguinity, Heritage, Province). Mineralium Deposita 8: 237-258

Liou JG, Maruyama S, Cho M (1987) Very-low grade metamorphism of volcanic and volcanoclastic rock-mineral assemblages and mineral facies. In: Frey $\mathbf{M}$ (ed) Low temperature metamorphism Blackie, USA: pp 59-113

Maucher A, Saupé F (1967) Sedimentarer Pyrit aus der Zinnorberlagerstatte Almadén (provinz Ciudad Real, Spanien). Mineralium Deposita 2: 312-317
Meschede M (1986) A method for discriminating between different type of mid-ocean ridge basalts and continental tholeiites with the Nb-Zr-Y diagram. Chem Geol 56: 207-218

Morata D, Higueras P, Domínguez-Bella S, Velasco F (1997) Presencia y significado de fuchsita en enclaves ultrabásicos de la roca frailesca de Almadén. Bol Soc Esp Minral 20A: $85-86$

Morency M, Mineau R, Zeller E, Dreschhoff G (1986) Are all fossil fuels really fossils? Oil and Gas J, June 2: 92-95

Nägler TF, Schäfer HJ, Gebauer D (1992) A Sm-Nd isochron on pelites $1 \mathrm{Ga}$ in excess of their depositional age and its possible significance. Geochin Cosmochim Acta 56: 789-795

Ortega E, Hernández A (1992) The mercury deposits of the Almadén syncline, Spain. Chron Rech Min 506: 3-24

Prado del C (1855) Sur la géologie d'Almadén, d'una partie de la Sierra Morena, et des montagnes de Toledo. Bull Soc Geol Fr (2ème série) 12: 182-204

Puigdefábregas C (1974) Estudio de las relaciones entre paleocorrientes y direcciones de mineralización en la Mina de Almadén. Internal Rep CGS

Potter RW II, Barnes HL (1978) Phase relations in the binary HgS. Am Mineral 63: 1143-1152

Ransome F (1921) The ore of the Almadén mine. Econ Geol 16: 313-321

Ridley J (1993) The relations between mean rock stress and fluid flow in the crust: with reference to vein- and lode-style gold deposits. Ore Geol Rev 8: 23-37

Rytuba JJ Heropoulos C (1992) Mercury - an important byproduct in epithermal gold systems. Contributions to mineral commodities. US Geol Surv Bull 1877, D1-D8

Rytuba JJ, Rye RO, Hernández, A, Dean JA, Arribas A Sr (1989) Genesis of Almadén type mercury deposits, Almadén, Spain. Int Geol Congr., Washington, vol 2, p. 2741

Saupé F (1967) Note préliminaire concernant la genèse du gisement de mercure d'Almadén. Mineralium Deposita 2: 26-33

Saupé F (1973) La géologie du gisement de mercure d'Almadén (Province de Ciudad Real, Espagne), Sciences de la Terre, Mem $29,342 \mathrm{p}$

Saupé F (1990) Geology of the Almadén mercury deposit, Province of Ciudad Real, Spain. Econ Geol 85: 482-510

Saupé F, Arnold M (1992) Sulphur isotope geochemistry of the ores and country rocks at the Almadén mercury deposit, Ciudad Real, Spain. Geochim Cosmochim Acta 56: 3765-3780

Sirot P, Ventre J (1973) Etude de la «roche frailesca et d'un groupe de sondages de la mine d'Almadén. Rap Univ Nancy, $46 \mathrm{p}$

Soldevila J (1983). Estudio geológico estructural de la terminación occidental del sinclinal de Almadén. Bol Geol Min 44-2: 93105

Tamain G (1972) Recherches géologiques et minières en Sierra Morena Oriental (Espagne). Thèse de Doctorat, Université París-Sud, Orsay, $648 \mathrm{p}$

Taylor SR, McLennan SM (1985) The continental crust. Its composition and evolution. Blackwell, Oxford. $312 \mathrm{p}$

Van der Veen RW (1924) The Almadén mercury ores and their connection with igneous rocks. Econ Geol 29: 146-156

Varekamp JC, Buseck PR (1984) The speciation of mercury in hydrothermal systems, with applications to ore deposition. Geochim Cosmoschim Acta 48: 177-185

White RS, McKenzie D (1995) Mantle plumes and flood basalts. J Geophy Res 100: 17 543-17 585

Yardley BW (1989) An introduction to metamorphic geology. Longman Scientific and Technical, Singapore, $248 \mathrm{p}$ 